Journal of Economics, Finance and Management Studies

ISSN(print): 2644-0490, ISSN(online): 2644-0504

Volume 4 Issue 03 March 2021

Article DOI: 10.47191/jefms/v4-i3-08, Impact Factor: 6.228

Page No.- 166-173

\title{
The Entrepreneurial University Model and Policy Implications for University Governance in Vietnam Public Universities
}

\author{
Van Toan Dinh ${ }^{1}$, Thi Cam Thuong Hoang ${ }^{2}$ \\ ${ }^{1}$ University of Economics and Business, Vietnam National University Hanoi, Hanoi, Vietnam \\ ${ }^{2}$ Department of Economics, Vinh University, Nghean, Vietnam
}

\begin{abstract}
Along with the advances of science and technology, higher education has had a substantial transformation towards autonomy associated with entrepreneurship, innovation, and creativity. Vietnam is facing the challenges of changes in governance for public universities. From the general theory and academic literature review of the entrepreneurial university, especially in organizational structure, the article offers policy suggestions to promote university governance in line with the trend of the transformation of entrepreneurial university model for public universities in Vietnam.
\end{abstract}

KEYWORDS: Entrepreneurial university, public university, university governance, Vietnam

\section{INTRODUCTION}

In the past, the primary missions of traditional universities were to train knowledgeable labors; research, and disseminate knowledge (first and second mission). Nowadays, universities have become smart educational institutions associated with entrepreneurship, innovation, creativity, and advanced governance models. This model is consistent with the high autonomy tendency in organizational structure, management, and operation to perform the third mission. This university model is called Entrepreneurial University, and its third mission is entrepreneurship, innovation, and creativity (Dinh Van Toan, 2020).

The change in university organizational structure and operation has been a trend in many parts of the world over the past two decades as a transition from the traditional to the entrepreneurial one. This model's main features are organizational structure and operation associated with the spirit of entrepreneurship, innovation based on autonomy mechanism. Based on an overview of academic studies, the following section of this article focuses on analyzing and clarifying the main characteristics of the organizational structure and operation of an entrepreneurial university. From the perspectives on the structural and organizational characteristics of the model and based on the recent research results in Vietnam, the article offers suggestions for governance changing in Vietnamese public universities.

\section{THEORETICAL BACKGROUND OF THE ENTREPRENEURIAL UNIVERSITY}

\subsection{Entrepreneurship academic and entrepreneurial university}

The concept of the entrepreneurial university (Etzkowitz, 1983, 2004) has contributed to change the strategic plan orientation of most universities worldwide. Universities operate more effectively when promoting entrepreneurship activities: knowledge and scientific research results commercialization through patent, franchises, and licensing or through business incubators and technology parks development (Bramwell and Wolfe, 2008). Etzkowitz (2004) called universities' ability to develop entrepreneurial activities were the second academic revolution. Nowadays, the commercialization of scientific research results is also seen as a role of the university as innovators. In addition to research and education, universities as knowledge centers have partnered with enterprises, public and private organizations in the regional innovation network to enhance research results commercialization, promote new business models, thereby take research and development operation to a higher level.

According to Yokoyama (2006), in universities, entrepreneurship is not necessarily understood with the idea of profitable and risk-taking, and highly commercial. However, it relates to the attitude of the universities in trying to financial autonomy, improve the capacity and efficiency of technology transfer. In a specific study of "third mission" activities of the university by Shore and McLauchlan (2012), authors clearly show that the nature and progression of these activities are the connection 


\section{The Entrepreneurial University Model and Policy Implications for University Governance in Vietnam Public Universities}

between research activities and the final commercialization of results which is a series of activities from innovative research introduction, patents, and technology license, entrepreneurship, incubation and company formation.

\subsection{Characteristics of entrepreneurial universities}

Over the past two decades, the goals and operation efficiency of universities all over the world have changed. From a separate educational institution, the universities have transformed into technology and socio-economic development committee institutions, and their mission has changed continuously over time. This change is aimed at a specific purpose: innovation and technology transfer. The people who promoted the use of the entrepreneurial university concept analyzed the university role in social development based knowledge. By introducing the "Triple Helix" model about the strong trilateral relationship between universities, industry, and government, the authors point out that universities have become the resources for entrepreneurship activities and play an increasingly important role in socio-economic development.

In order to perform well the three main pillars: education, research and contribution to socio-economic development, university organizational structure is designed to promote entrepreneurship, such asthe establishment of business incubators to assist in creating new projects which develop from research groups to entrepreneurship businesses (Costa and Torkomian, 2008; Degroof and Roberts, 2004; Vohora et al., 2004). Besides, universities must have patent policies and establish technology transfer agencies/departments (TTOs) to bridge scientific researchers with businesses, entrepreneurs, and public or private finance sources.

Existence of a structure dedicated to technology transfer (including TTOs, incubator) and internal management mechanisms that allow to specialize support services for networks creation of potential industry partners, intellectual property management, and new business development. According to Macho-Stadler et al. (2007), in terms of university organizational structure, creating a specialized TTO is essential for the partnership development with industry. TTOs facilitate the technology transfer of intellectual property licensing to existing companies or companies that start-up from universities (Hellmann, 2007; Siegel et al., 2007). However, before establishing business incubators and TTOs, universities must possess excellent scientific research results in order to create technology development sources for entrepreneurship businesses. Scientific research can be considered as the driving force of the entrepreneurial university.

So far, academics and managers have agreed that typical activities of business entrepreneurship in universities include three main groups: Technology transfer; Intellectual property commercialization, and formation of new businesses from universities. Unlike traditional universities, which have the fundamental goal of knowledge creation, entrepreneurial universities aim to apply and exploit knowledge. This is a critical characteristic reflected in the declared mission and development strategy of a university (Chang et al., 2016). Exploiting research results is the sum of works aimed at achieving the highest results and efficiency in scientific research results commercializing. These activities must meet the market demand, bring economic efficiency, increase income for the university, lecturers, and researchers. Based on the synthesis of research results, in terms of operation, the entrepreneurial university has the following characteristics:

(i) Enhancing awareness and perceptions of business: Universities provide entrepreneurship lectures and information to increase students' and lecturers' awareness about the way to identify new markets or technology opportunities. According to Rasmussen and Borch (2010), entrepreneurship classes are active because students want to start-up and develop their own business plans. In addition, entrepreneurship classes also encourage students to develop new technology-based companies at university incubators, stimulate the technology flow from university to market (Aaboen, 2009).

(ii) External linkage: having policies and mechanisms for lecturers to participate internal and external applied research. Abreu and Grinevich (2013) argue that, because applied research is often closer to market demand, it is easier for researchers to find applications for their technology. This can also be done when the university has connected with local and global industries network (Bramwell and Wolfe, 2008; Rasmussen and Borch, 2010).

(iii) Access and exploit university resources: entrepreneurs can use laboratories and scientific equipment for testing and experimenting. They 'don't have to invest in additional resources for scientific research. All of their funds should be devoted to product development. However, in practice, it is necessary to have agreements between companies and universities to legitimize these relationships not only internally but also with the market (Rasmussen and Borch, 2010).

(iv) Implementing business entrepreneurship support activities: Universities provide entrepreneurship support infrastructure. In addition to the premises, laboratory and scientific research equipment, the functional units that perform these supports may include: Entrepreneurship support centers, Technology transfer; Business Incubator or Technology Park etc. These are the components of the main entrepreneurship structure as described by Audretsch (2009) also pointed out that with these activities, the entrepreneurial university can facilitate knowledge spread to companies and non-profit organizations. 


\section{The Entrepreneurial University Model and Policy Implications for University Governance in Vietnam Public Universities}

(v) Scientific research: the entrepreneurial university has a structure with research groups and postgraduate courses. One of the most critical aspects of technology transfer is the engagement activities of businesses in university training and scientific research programs. In which the university is the main source of information along with the active role of various organizations such as business incubators, science parks, technology parks etc, to support business development and entrepreneurship based on existing resources and external resources.

\subsection{Organizational structure of entrepreneurial universities}

In theoretical models, scholars have had many studies to explain the phenomenon of universities being organized and operated in the direction of business entrepreneurship, also known as "entrepreneurial university." Some typical studies are Clark (1998); Etzkowitz (1998, 2003); Guerrero et al. (2006); Rothaermel et al. (2007); Gibb et al. (2019); Guerrero and Urbano (2010); Sooreh et al. (2011); Farsi et al. (2012); Chang et al. (2016); Dalmarco et al. (2018); Boffo and Cocorullo (2019) and Dinh Van Toan (2020). A prominent common point in the transformation activities in these universities, as pointed out by the authors, is that vigorously deploying business entrepreneurship activities, along with developing the entrepreneurship and innovation spirit at all levels: organization, groups, and individuals (Clark, 1998; Etzkowitz, 1998; Farsi et al., 2012). Implementation of these activities plays an essential role of cooperation in the model of Triple - Helix: government, universities, and enterprises to promote technology transfer and enterprise formation (Etzkowitz, 2008). According to Ropke (1998), these universities contribute to build entrepreneurship capacity for officials and learners in the university and play an increasingly important role in the knowledge economy and modern society.

On the basis of the theoretical and empirical research results, Chang et al. (2016) pointed out the differences compared with traditional universities, including organizational structure and activities of the entrepreneurial university (Table 1).

Table 1. Traditional universities and entrepreneurial universities

\begin{tabular}{|l|l|l|}
\hline & Traditional universities & Entrepreneurial universities \\
\hline Target & - Creation of knowledge & $\begin{array}{l}\text { - Knowledge creation } \\
\text { - Knowledge application and exploitation }\end{array}$ \\
\hline $\begin{array}{l}\text { Organizational } \\
\text { structure }\end{array}$ & $\begin{array}{l}\text { - Function Departments; Faculties; } \\
\text { Laboratory; Research Centers... }\end{array}$ & $\begin{array}{l}\text { - Function Departments; Faculties; Laboratory; Research Center... } \\
\text { - Transfer support services; Incubators; Spin-off Companies }\end{array}$ \\
\hline Operation & - Academic routines & - Academic routines- Research commercialization \\
\hline
\end{tabular}

Source: Chang et al. (2016)

In addition to the basic goal of a traditional university is knowledge creation, entrepreneurial university aims to apply and exploit knowledge. This is an important characteristic embodied in a university's declared mission and development strategy. They are exploiting research results not only at the dissemination and transfer of knowledge to serve the community but also to overall work to achieve the highest results and efficiency in commercializing scientific research results. These activities must aim to meet the market demand, bring economic efficiency, increase income sources for the university, and increase income for staff, lecturers and researchers. With such a goal, the university conducts many activities. The final manifestation of the chain of activities in efforts to achieve this goal is technology transfer, commercialization, and business development on a research and development basis. Yokoyama's research focuses on the attitude of universities in trying to be autonomous about technology transfer and finance or enhancing university and scientists' responsibility for the society in general. The results show that this change leads to change in institutions, governance structures, and operation mechanisms. Therefore, the five forms of low-to-high development of the university model proposed by Yokoyama can be considered as a direct result of the process of forming entrepreneurship in universities and developing the entrepreneurial university model (Table 2).

Table 2. Five entrepreneurial types of universities

\begin{tabular}{|l|l|l|}
\hline Order & Types & $\begin{array}{l}\text { The characteristic of governance structures and operation } \\
\text { mechanism }\end{array}$ \\
\hline \multirow{3}{*}{1} & A Prototype (e.g. Tokyo University) & $\begin{array}{l}\text { - Increase of institutions discretion } \\
- \text { The introduction of entrepreneurial culture } \\
- \text { Review in governance (e.g. increasing the power of the } \\
\text { University Centre and university President), management, } \\
\text { leadership, and internal funding }\end{array}$ \\
\hline
\end{tabular}




\section{The Entrepreneurial University Model and Policy Implications for University Governance in Vietnam Public Universities}

\begin{tabular}{|c|c|c|}
\hline & & $\begin{array}{l}\text { - Set-up of institutional strategic planning } \\
\text { - Emphasis on the significance of enhancing accountability }\end{array}$ \\
\hline 2 & $\begin{array}{l}\text { An Entrepreneurial-oriented University } \\
\text { (e.g. Waseda University) }\end{array}$ & $\begin{array}{l}\text { - The extension of entrepreneurial activities } \\
\text { - Market-oriented institutional policy } \\
\text { - Conflict between academic and entrepreneurial values } \\
\text { - Introduction of managerialism }\end{array}$ \\
\hline 3 & $\begin{array}{l}\text { A Fledgling Entrepreneurial University } \\
\text { (e.g. Nottingham Trent University) }\end{array}$ & $\begin{array}{l}\text { - Limitation of public funding dependency } \\
\text { - Self-identity as an entrepreneurial university } \\
\text { - Contribution to the regional economy }\end{array}$ \\
\hline 4 & $\begin{array}{l}\text { An Adaptive Entrepreneurial University } \\
\text { (e.g. University of Surrey) }\end{array}$ & $\begin{array}{l}\text { - Institutional self-determination } \\
\text { - Substantial amount of income from external funding } \\
\text { - Market-oriented governance and management structure } \\
\text { - Integration of entrepreneurial and academic culture }\end{array}$ \\
\hline 5 & An Ideal Type & $\begin{array}{l}\text { - Autonomous and self-reliant institution } \\
\text { - Clear risk sharing and responsibility among actors involved in } \\
\text { the entrepreneurial activities } \\
\text { - Integration of entrepreneurial and academic culture, and } \\
\text { managerial and collegial culture in an institution with no conflict } \\
\text { between them }\end{array}$ \\
\hline
\end{tabular}

Source: Yokoyama (2006)

In fact, in the entrepreneurial university, there are not the only establishment of "academic enterprises" (enterprises associated with training and research activities), but also enterprises or other affiliated organizations operating belong to different levels and classes. In addition to the goal of profit, business development and enterprise formation in the university have differences compared to outside enterprises in transferring knowledge, technology, and new ideas to the market. In particular, these activities contribute to perfecting the organization, management structure, and operation model according to the entrepreneurial culture associated with advanced university governance. According to Bercovitz and Feldman (2006), business development and enterprise formation activities in universities positively contribute to the development of the knowledge economy and contribute to social progress. Since positive contribution, many countries in the world often have policies to support those activities of the entrepreneurial university and promote university governance changing. According to a summary in a recent study of the author, the entrepreneurial university can not separate an external environment that promotes innovation and commercialization activities (Dinh Van Toan, 2020). This environment forms an ecosystem for business development and enterprise formation through entrepreneurship support associated with innovation and creativity from academia (Figure 1).

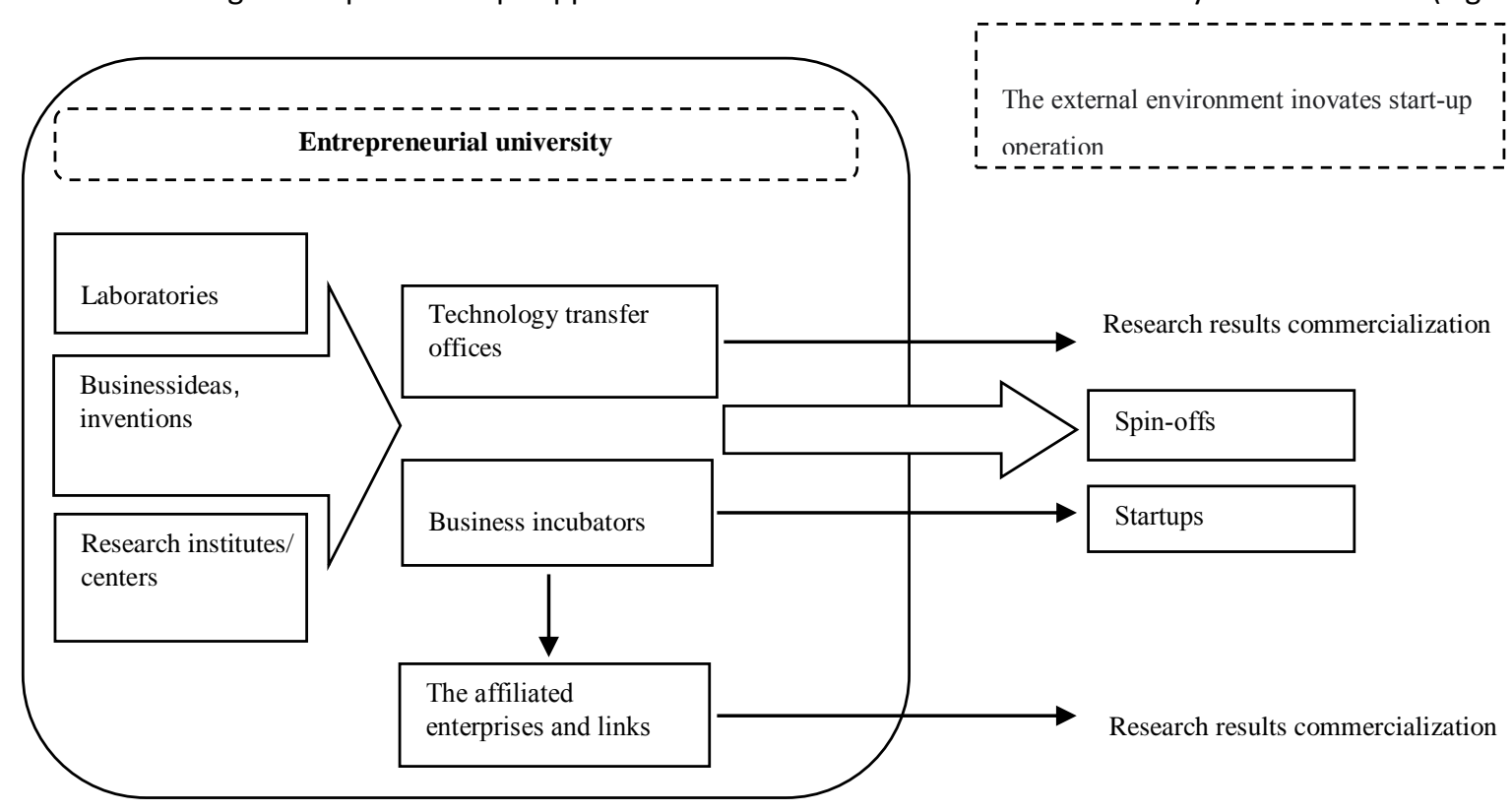

Figure 1. Entrepreneurial university development model (Source: Dinh Van Toan, 2020) 


\section{The Entrepreneurial University Model and Policy Implications for University Governance in Vietnam Public Universities}

In Figure 1, universities need to have research capacity, laboratories, and research institutes centers come up with new business ideas, new technologies and inventions, and useful solutions. To be able to commercialize scientific research products, technology transfer offices, and business incubators have a decisive role. The effective operation of these units will promote technology transfer and research results of scientists and universities commercialization to outside enterprises (Dinh Van Toan, 2016) and promote the formation of new businesses.

In addition, universities need to have a comprehensive establishment in the university structure, including incubation and transfer support units (TTOs and incubators) along with promoting commercial feasibility studies in research units (laboratory, center, research institute). This helps motivate each other: the support unit assists the university and the lecturer to form companies; In turn, the companies that form and call for investment capital create the need to contribute funding and promote the operation of these units. On the other hand, the cooperative activities of these enterprises with individuals and organizations in the university will have an impact on the starting up intentions and aspirations of lecturers and researchers and increase the need for transfer support units in the university organizational structure.

\section{REASON FOR THE SLOW TRANSITION IN VIETNAMESE PUBLIC UNIVERSITIES}

The transformation to become a entrepreneurial university has been implemented by many universities around the world, especially over the past two decades (Dinh Van Toan, 2020). The author's recent research results show that leaders and managers in some Vietnam public universities have clearly expressed the desire to increase revenue from business of enterprises in the university, especially in self-control tendencies. However, until 2019, only one university, Hanoi University of Technology, has established a technology incubator and supported a successful business establishment, that is BK Holdings Company, which was organized under the group of businesses model. Besides the education sector (BK Holdings Educations), the technology commercialization model of BK Holdings is very successful thanks to three main groups: BK Holdings Technology consisting of 5 companies conducting research and transfer; transfer support services (TTO), and business incubation (BK Holdings Incubator) to implement start-up projects (Dinh Van Toan, 2020). Through research and surveys of several public universities across the country on the business establishment and entrepreneurial activities in universities (Dinh Van Toan, 2020), the results show that model transformation and business development and entrepreneurship spirit are limited due to the following main reasons:

- Government policies and regulations are not consistent and have not created a start-up ecosystem in universities. First of all, the binding regulations on the establishment and in the management of enterprises participation for officials and employees are barriers to the businesses development in universities. In addition, there are obstacles and complexity in the regulations and operating mechanisms of public universities in the use of state budgets, assets and land allocated by the State when forming a joint stock enterprise or the contributions of the parties, including staffs and leturers.

- The governance structure of the universities has not met the autonomy mechanism, so it is difficult to apply policies to promote start-up operation in universities. Key decisions on financial policy and human resource policy are still subject to authorization from the line ministry and the line management ministry. In addition, the role and the operation way of university board is fuzzy and confused in controlling the direction, strategic planning and risk management.

- Scientific research activities in Vietnam public universities are still mainly based on the State budget. Research from the enterprises orders, the application and transfer of scientific research results to practical production and business to get profits for the university is still very costly. The reason is that resources of universities in scientific research investment are still limited; scientific and technological products that can be applied and commercialized to meet market demand are still low.

- The universities need and ability to link with businesses are not high due to lack of motivation and linkage mechanism between the two sides. Capacity and equipment for universities applied research are limited, researching time towards commercialization is long, while enterprises need to transfer technology is quick. This leads to a large gap between scientific research and market demand. Schools lack a specialized agency which has knowledge of the business as a bridge for the university to engage with a business. Especially barriers from financial mechanisms, public property management and staff and employee management in public universities not only do not promote scientific research and transfer for commercialization, but also prevent lecturers and researchers from participating in business association projects and establishing academic enterprises.

- Staff, lecturers, and learners at public universities have not paid attention to entrepreneurial activities associated with innovation and creativity. In addition to creating products that can be transferred from scientific research, transfer and commercialization must be the needs of organizations and individuals in the university and should be encouraged and supported in implementation. Therefore, policies and mechanisms should ensure rights and interests between parties, ensure democracy in academic activities, promote technology transfer and encourage start-ups, innovation, and creativity. 


\section{The Entrepreneurial University Model and Policy Implications for University Governance in Vietnam Public Universities}

\section{SOME POLICY SUGGESTIONS FOR UNIVERSITY GOVERNANCE INNOVATION TOWARDS STARTING UP}

From the research results on advanced governance structures in the entrepreneurial university model above, some policy suggestions on university governance for public universities in Vietnam are outlined below.

First, the government needs to play a leading role in establishing and coordinating the government - university - industry tripartite relationship and creating an environment that promotes entrepreneurship. In order to implement this role, it is crucial to establish institutions and policy systems to promote the business - university linkage and commercial environment, business development in universities. In addition, the specific mechanisms to implement autonomy in organizational structure, resources allocation (finance, assets, and human resources) in universities will be pushes and decisive leverages in entrepreneurial model development associated with autonomy.

Second, encourage and promote the innovation and creativity spirit to diversify and improve quality and commercialize scientific research results from universities. These activities provide resources for applied research and serve as a prerequisite for technology transfer and commercialization. Universities need to actively find scientific research investment funds and technology development through orders and contracts of individuals and businesses. In addition, universities also need to strengthen training activities to grow and promote the entrepreneurship, innovation, and creative spirit in the universities, which is a purely academic environment according to traditional concepts.

Third, universities need to change perceptions, reform their organizational structure and apparatus in the direction of promoting entrepreneurship. Specifically, it is necessary to form units to support and implement knowledge sharing, technology transfer and establish enterprises to commercialize scientific research results. The business activities of these units provide the university and scientists to have legitimate income, reduce the funding burden for research and training activities. On the other hand, business results, as well as exchange and association activities, motivate scientists, lecturers, and students in scientific research, innovation and creativity - a prerequisite for entrepreneurial university development.

Fourth, universities need to strengthen cohesion with business and the community. To do this, the university must change their perceptions and views of cooperation on the principle of enhancing mutual understanding and bringing benefits to all parties; building database system of individuals and partner businesses; actively accessing funding sources, orders and investing in research and trial production which do not use the state capital. In addition, the university should have appropriate policies and regulations along with a cooperation and remuneration mechanism to encourage scientists and individuals to actively register, establish and transfer intellectual property rights to exploit cooperations with businesses.

Fifth, in addition to organizational structure reform, universities need to soon implement institutional and management methods reforms in the direction of increasing autonomy and self-responsibility for units in the university. The traditional hierarchical three-level governance mechanism (university, faculties, and disciplines) needs to be improved to promote accountability with academic freedom, respect, and a democratic environment. These are also the basic principles of advanced university governance in terms of the transition to a entrepreneurial university model.

\section{CONCLUSION}

The traditional universities, having highly administrative management and administration, depending on the governing unit - are having a strong transition to a entrepreneurial university model. Accordingly, the university is not framed in the walls of the lecture halls, classrooms or laboratories, but extends the connection with businesses and society to become an education ecosystem, research, innovation, and creativity and meet the requirements of related parties. In this model, the outstanding feature is the innovation in the organizational structure and governance mechanism to support and enhance business transfer, commercialization, and entrepreneurial activities, including business development.

Researching the organizational and operational characteristics of a entrepreneurial university, the article provides suggestions on policies related to university governance in the transition of Vietnam public universities. The given suggestions in order to overcome the shortcomings and barriers from outside and inside of the university have been mentioned by many recent studies. In addition to improving and synchronizing the legal and institutional system to form an entrepreneurial and autonomous ecosystem for public universities, the universities also need to promote the spirit of initiative, innovation, and creativity suitable with the governance model of entrepreneurial universities. The innovation of university governance should be done systematically from institutions, state management to the organizational model and university governance in order to build and promote thoroughly autonomy and accountability of universities, which associated with academic freedom in universities.

\section{REFERENCES}

1) Aaboen, L. 2009. Explaining Incubators Using Firm Analogy. Technovation, 29(10): 657-670. 


\section{The Entrepreneurial University Model and Policy Implications for University Governance in Vietnam Public Universities}

https://doi.org/10.1016/j.technovation.2009.04.007

2) Abreu, M. and Grinevich, V. 2013. The Nature of Academic Entrepreneurship in the UK: Widening The Focus On Entrepreneurial Activities. Research Policy, 42(2): 408-422. https://doi.org/10.1016/j.respol.2012.10.005

3) Auretsch, D.B. 2009. Strategic Entrepreneurship: Exploring Different Perspectives of an Emerging Concept. Entrerpreneurship Theory and Practice, 33(1): 1-17. https://doi.org/10.1111/j.1540-6520.2008.00278.x

4) Audretsch, D.B. 2014. From the Entrepreneurial University to the University for the Entrepreneurial Society. The Journal of Technology Transfer, 39(3): 313-321.

5) Boffo, S. and Cocorullo, A. 2019. University Fourth Mission, Spin-offs and Academic Entrenreneurship: Connecting Public Policies with New Missions and Management Issues of Universities. Higher Education Forum, 16: 125-142.

6) Bramwell, A. and Wolfe, D.A. 2008. Universities and Regional Economic Development: The Entrepreneurial University of Waterloo. Research Policy, 37(8): 1175-1187. https://doi.org/10.1016/j.respol.2008.04.016

7) Clark, B.R. 1998. Creating Entrepreneurial Universities: Organizational Pathways of Transformation, Issues in Higher Education, Elsevier, New York.

8) Clark, B. R. 1999. Creating Entrepreneurial Universities: Organizational Pathways of Transformation, Oxford: IAU Press and Pergamon.

9) Chang, Y. C., Yang, P.Y., and Chen, M.H. 2009. The Determinants of Academic Research Commercial Performance, Towards an Organizational Ambidexterity Perspective. Research Policy, 38(6): 936-946.

https://doi.org/10.1016/j.respol.2009.03.005

10) Chang, Y. C., Yang, P.Y., Martin, B.R., Chi, H.R., and Tsai-Lin, T.F. 2016. Entrepreneurial Universities and Research Ambidexterity: A Multilevel Analysis. Technovation, 54: 7-21. http://dx.doi.org/10.1016/i.technovation.2016.02.006.

11) Costa, L.B. and Torkomian, A.L. 2008. Um Estudo Exploratório sobre um Novo Tipo de Empreendimento: os Spin-offs Acadêmicos. Revista de Administração Contemporânea, 12(2): 395-427.

12) Dalmarco G., Hulsink W., and Blois G. V. 2018. Creating entrepreneurial universities in an emerging economy: Evidencefrom Brazil. Technological Forecasting \& Social Change, 135: 99-111. doi:10.1016/j.techfore.2018.04.015.

13) Degroof, J.J., and Roberts, E.B. 2004. Overcoming Weak Entrepreneurial Infrastructures for Academic Spin-Off Ventures. The Journal of Technology Transfer, 29(3-4): 327-352. DOI: 10.1023/B:JOTT.0000034126.23592.23

14) Dinh Van Toan, Hoang Van Hai, Nguyen Phuong Mai. 2016. The Role of Entrepreneurship Development in Universities to Promote Knowledge Sharing: The Case of Vietnam National University Hanoi, Proceedings of Asia Pacific Conference on Information Management 2016: Common Platform to A Sustainable Society In The Dynamic Asia Pacific, Vietnam National University Press, October, 2016.

15) Dinh Van Toan. 2020. Entrepreneurial Universities and the Development Model for Public Universities in Vietnam. International Journal of Entrepreneurship, Vol. 24, Issue 1, 2020. https://www.abacademies.org/articles/Entrepreneurialuniversities-the-development-model-for-public-universities-in-vietnam-24-1.pdf

16) Etzkowitz, H. 1983. Entrepreneurial Scientists and Entrepreneurial Universities in American Academic Science. Minerva, 21(2/3): 198-233. https://doi.org/10.1007/BF01097964

17) Etzkowitz, H. 1998. The Norms of Entrepreneurial Science: Cognitive Effects of the New University - Industry Linkages. Research Policy, 27(8): 823-833. https://doi.org/10.1016/S0048-7333(98)00093-6

18) Etzkowitz, H. 2003. Research Group as 'Quasi-Firm'? The Invention of the Entrepreneurial University. Research Policy, 32(1): 109-121. https://doi.org/10.1016/S0048-7333(02)00009-4

19) Etzkowitz, H. 2004. MIT and The Rise of Entrepreneurial Science, Taylor \& Francis, Oxford.

20) Etzkowitz, H. 2008. The Triple Helix: University-Industry-Government Innovation in Action, Taylor and Francis, London.

21) Farsi, J.Y., Imanipour, N., and Salamzadeh, A. 2012. Entrepreneurial University Conceptualization: Case of Developing Countries. Global Business and Management Research, 4(2): 193-204.

22) Gibb, A. A., Haskins, G., and Robertson. 2009. Leading the entrepreneurial university: Meeting the entrepreneurial development needs of higher education institutions. National Council for Graduate Entrepreneurship (NCGE), pp. 54. (Retrieved from www.ncge.org.uk)

23) Guerrero, M. and Urbano, D. 2010. The Development of an Entrepreneurial University. The Journal of Technology Transfer, 37(1): 43-74. DOI: 10.1007/s10961-010-9171-x.

24) Hellmann, T. 2007. The Role of Patents for Bridging the Science To Market Gap. Journal of Economic Behavior \& Organization, 63(4): 624-647. https://doi.org/10.1016/j.jebo.2006.05.013 


\section{The Entrepreneurial University Model and Policy Implications for University Governance in Vietnam Public Universities}

25) Macho-Stadler, I., Pérez-Castrillo, D., and Veugelers, R. 2007. Licensing of University Inventions: The Role of A Technology Transfer Office. International Journal of Industrial Organization, 25(3): 483-510. https://doi.org/10.1016/j.ijindorg.2006.06.001

26) Rasmussen, E. and Borch, O.J. 2010. University Capabilities in Facilitating Entrepreneurship: A Longitudinal Study of SpinOff Ventures At Mid-Range Universities. Research Policy, 39(5): 602-612. https://doi.org/10.1016/j.respol.2010.02.002

27) Rasmussen, E., Mosey, S., and Wright, M. 2014. The Influence of University Departments on the Evolution of Entrepreneurial Competencies in Spin-Off Ventures. Research Policy 43(1): 92-106. https://doi.org/10.1016/j.respol.2013.06.007

28) Rasmussen, E. and Wright M. 2015. How Can Universities Facilitate Academic Spin-Offs? An Entrepreneurial Competency Perspective. The Journal of Technology Transfer, 40(5): 782-799.

29) Ropke, J. 1998. The Entrepreneurial University: Innovation, Academic Knowledge Creation And Regional Development In A Globalized Economy, http://www.staff.uni-marburg.de/ roepke/Documents/entreuni.pdf.

30) Rothaermel F.T., Agung S.D. and Jiang L. 2007. University Entrepreneurship: A Taxonomy of the Literature. Industrial and Corporate Change, 16(4): 691-791. https://doi.org/10.1093/icc/dtm023

31) Siegel, D.S., Veugelers, R., and Wright, M. 2007. Technology Transfer Offices and Commer-Cialization of University Intellectual Property: Performance and Policy Implications. Oxford Review of Economic Policy, 23(4): 640-660. https://doi.org/10.1093/oxrep/grm036

32) Sooreh, L.K., Salamzadeh, A., Safarzadeh, H., and Salamzadeh, Y. 2011. Defining and Measuring Entrepreneurial Universities: A Study in Iranian Context Using Importance-Performance Analysis and TOPSIS Technique. Global Business and Management Research: An International Journal, 3(2): 182-199.

33) Sporn, B. 2001. Building Adaptive Universities: Emerging Organisational Forms Based on Experiences of European and US Universities. Education and Management, 7(2): 121-134. https://doi.org/10.1080/13583883.2001.9967046

34) Vohora, A., Wright, M., and Lockett, A. 2004. Critical Junctures in the Development of University High-Tech Spinout Companies. Research Policy 33 (1): 147-175. https://doi.org/10.1016/S0048-7333(03)00107-0

35) Yokoyama K. 2006. Entrepreneurialism in Japanese and UK Universities: Governance, Management, Leadership and Funding. Higher Education, 52: 523.555. https://doi.org/10.1007/s10734-005-1168-2 